\title{
Gonococcal orbital cellulitis
}

\author{
Inês Oliveira, ${ }^{1}$ Ana Mouzinho, ${ }^{2}$ José Gonçalo Marques ${ }^{2}$
}

${ }^{1}$ Pediatrics Department, Hospital de São Bernardo, Setubal, Portugal

${ }^{2}$ Infectious Diseases Unit, Department of Paediatrics, Centro Hospitalar Lisboa Norte EPE, Lisboa, Portugal

\section{Correspondence to}

Dr Inês Oliveira,

inesfigueiredoliveira@gmail.com

Accepted 12 June 2019

\section{DESCRIPTION}

A 17-year-old healthy boy presented to the emergency room with conjunctival hyperemia, purulent discharge and periorbital swelling of the right eye, lasting for 4 days, without improvement with topical chloramphenicol. On the day of admission, he started ocular pain and photophobia. There was no history of eyelid trauma, sinusitis or fever.

On examination, he presented periorbital swelling, proptosis, chemosis, purulent discharge, hyperemia and conjunctival petechiae of the right eye (figure 1). Ocular movements were maintained,

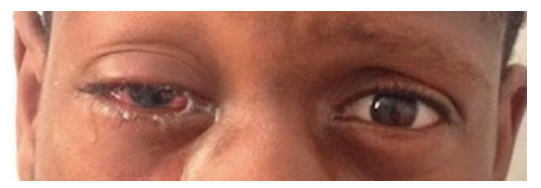

Figure 1 Periorbital swelling, proptosis, purulent discharge, hyperemia of the right eye.

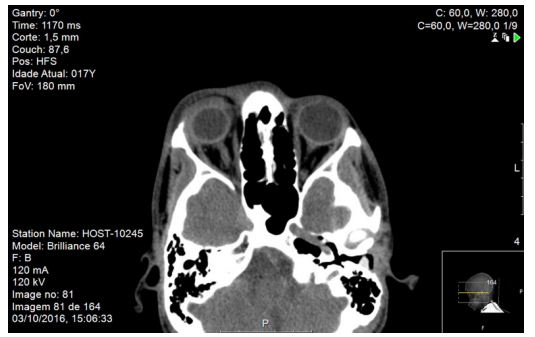

Figure 2 Orbital CT scan showing protrusion of the right orbit. but painful. He also had purulent urethral discharge, lasting for 3 weeks.

The blood work showed a slight increase on C-reactive protein $(3.99 \mathrm{mg} / \mathrm{dL}-U L N \quad 0.5 \mathrm{mg} /$ $\mathrm{dL})$. The CT scan of the orbits revealed postseptal extension of the inflammatory process affecting extra and intraconical fat (figure 2). A diagnosis of right orbital cellulitis (OC) was made. Assuming gonococcal oetiology for both urethritis and OC, he started on intravenous (IV) ceftriaxone and topical levofloxacin and was given a single dose of oral azithromycin, for potential chlamydia coinfection. The culture from both conjunctival and urethral swabs identified a non-penicillinase-producing strain of Neisseria gonorrhoeae, susceptible to the therapy in course. Polymerase chain reaction for Chlamydia trachomatis in the urethral discharge was also positive. Blood cultures were sterile. He was discharged after 8 days of IV and topical therapy, with regression of ocular inflammatory signs and urethral exudate. Follow-up showed no sequels. HIV and syphilis serologies were negative. He denied unprotected sex, but the sexual partner was notified and treated.

OC is a common finding in paediatrics, usually resulting from sinus or dental infections, trauma or conjunctivitis. The most frequent pathogens in bacterial orbital cellulitis are gram-positive cocci, such as Staphylococcus aureus and Streptococcus species and gram-negative bacilli like Haemophilus influenzae. ${ }^{1}$ Here we present the case of an healthy adolescent with gonococcal OC, which is a rare manifestation in the paediatric age especially outside the neonatal period and in immunocompetent children, with very few cases reported (table 1$){ }^{2}$

Table 1 Reported cases of preseptal and postseptal gonococcal cellulitis, with only one postseptal case in paediatric age

\begin{tabular}{|c|c|c|c|c|}
\hline Author & $\begin{array}{l}\text { Age } \\
\text { (years) }\end{array}$ & Clinical manifestation & Treatment options & Outcome \\
\hline $\begin{array}{l}\text { Pereira-Ospina } \\
\text { et } a l^{4}\end{array}$ & 2 & $\begin{array}{l}\text { Periorbital swelling and purulent discharge from } \\
\text { the right eye. }\end{array}$ & $\begin{array}{l}\text { Ceftriaxone } 100 \mathrm{mg} / \mathrm{kg} / \text { day intravenous for } 10 \text { days; } \\
\text { Ampicillin-sulbactam } 50 \mathrm{mg} / \mathrm{kg} / \text { day (after } \\
\text { discharge). }\end{array}$ & Complete resolution \\
\hline Yao and Wang ${ }^{5}$ & 22 & $\begin{array}{l}\text { Painful left eye with periorbital swelling and } \\
\text { purulent discharge; fever }\end{array}$ & $\begin{array}{l}\text { Ceftriaxone } 1 \mathrm{~g} / \text { day intravenous with oral } \\
\text { clarithromycin } 500 \mathrm{mg} / \text { day (empirical treatment of } \\
\text { possible Chlamydia coinfection), for } 7 \text { days. }\end{array}$ & Complete resolution \\
\hline $\begin{array}{l}\text { Annan and } \\
\text { Boag }^{3}\end{array}$ & 39 & $\begin{array}{l}\text { Purulent discharge from the left eye, } \\
\text { conjunctival injection and periorbital oedema. }\end{array}$ & $\begin{array}{l}\text { Ceftriaxone } 1 \mathrm{~g} / \text { day intramuscular, for } 10 \text { days; } \\
\text { Oral doxycycline (empirical treatment of possible } \\
\text { Chlamydia coinfection) for } 1 \text { week. }\end{array}$ & Residual corneal scarring \\
\hline Hegde et $a l^{6}$ & 19 & $\begin{array}{l}\text { Red and painful left eye with purulent } \\
\text { discharge. }\end{array}$ & Ceftriaxone $2000 \mathrm{mg} /$ day intravenous for 10 days. & Increase in corneal thickness \\
\hline Raja and Singh ${ }^{1}$ & 42 & $\begin{array}{l}\text { Periorbital swelling, purulent discharge, orbital } \\
\text { pain, tenderness and erythema of both eyes. }\end{array}$ & $\begin{array}{l}\text { Cefuroxime and gentamicin for } 48 \text { hours } \\
\text { Oral cefuroxime for } 1 \text { week and topical cefuroxime } \\
\text { and gentamicin }\end{array}$ & Complete resolution \\
\hline Henderson et al ${ }^{7}$ & 31 & $\begin{array}{l}\text { Periorbital erythema, swelling, conjunctival } \\
\text { injection, chemosis and purulent discharge of } \\
\text { the right eye. }\end{array}$ & $\begin{array}{l}\text { Flucloxacillin, ampicillin and intravenous } \\
\text { metronidazole } 5 \text { day followed by oral therapy for } \\
7 \text { days }\end{array}$ & Complete resolution \\
\hline Frazier et $a l^{2}$ & 15 & $\begin{array}{l}\text { Right periorbital oedema, purulent discharge, } \\
\text { orbital pain and tenderness, fever. }\end{array}$ & Penicillin G potassium intravenous, 7 days & Complete resolution \\
\hline
\end{tabular}


The OC was probably due to self-inoculation from gonococcal urethritis. N. gonorrhoeae is an uncommon cause of OC in the paediatric age. Nevertheless, we should consider this aetiology, especially in sexually active adolescents, since it may be associated with severe manifestations, such as ulceration and perforation of the cornea. ${ }^{3}$ It is essential to suspect and treat the disease early, and also to ensure follow-up of these adolescents and to reinforce safe behaviours.

\section{Learning points}

Gonoccocal orbital cellulitis is rare in paediatric age, but should be suspected in sexually active adolescents when associated with urethritis.

- Prompt diagnosis and treatment are important to prevent complications, such as ulceration and perforation of the cornea

Contributors 10 did data acquisition, writing and approval of the manuscript. AM did revision and approval of the manuscript. JGM did interpretation of the data, revision and approval of the manuscript.
Funding The authors have not declared a specific grant for this research from any funding agency in the public, commercial or not-for-profit sectors.

Competing interests None declared.

Patient consent for publication Parental/guardian consent obtained.

Provenance and peer review Not commissioned; externally peer reviewed.

\section{REFERENCES}

1 Raja NS, Singh NN. Bilateral orbital cellulitis due to Neisseria gonorrhoeae and Staphylococcus aureus: a previously unreported case. J Med Microbiol 2005;54(Pt 6):609-11.

2 Frazier JJ, Miller J, Pickering LK. Orbital cellulitis due to Neisseria gonorrhoeae in an enucleated socket. Arch Ophthalmol 1979;97:2345-6.

3 Annan NT, Boag FC. Outpatient management of severe gonococcal ophthalmia without genital infection. Int J STD AIDS 2008;19:573-4.

4. Pereira-Ospina RP, Pinzón-Salamanca JY, Suescún-Vargas JM, et al. Neisseria gonorrhoeae: un agente causal infrecuente de celulitis periorbitaria en un niño. Arch Argent Pediatr 2017;115:e243-e246.

5. Yao $\mathrm{HY}$, Wang $\mathrm{CH}$. Preseptal cellulitis caused by Neisseria gonorrhoeae: a rare disease need to be vigilant. J Microbiol Immunol Infect 2017:50:397-8.

6. Hegde V, Smith G, Choi J, et al. A case of gonococcal kerato-conjunctivitis mimicking orbital cellulitis. Acta Ophthalmol Scand 2005;83:511-2.

7. Henderson TRM, Booth AP, Morrell AJ. Neisseria gonorrhoeae: a previously unreported cause of pre-septal cellulitis. Eye 1997;11:130-2.

Copyright 2019 BMJ Publishing Group. All rights reserved. For permission to reuse any of this content visit https://www.bmj.com/company/products-services/rights-and-licensing/permissions/

BMJ Case Report Fellows may re-use this article for personal use and teaching without any further permission.

Become a Fellow of BMJ Case Reports today and you can:

- Submit as many cases as you like

- Enjoy fast sympathetic peer review and rapid publication of accepted articles

- Access all the published articles

- Re-use any of the published material for personal use and teaching without further permission

\section{Customer Service}

If you have any further queries about your subscription, please contact our customer services team on +44 (0) 2071111105 or via email at support@bmj.com.

Visit casereports.bmj.com for more articles like this and to become a Fellow 